\title{
THE CORRECT NAME FOR PENTAS SCHIMPERIANA IS PENTAS SCHIMPERI (RUBIACEAE)
}

\author{
JAN J. WIERINGA \\ Nationaal Herbarium Nederland, Wageningen University branch, Herbarium Vadense, \\ Biosystematics Group, Generaal Foulkesweg 37, 6703 BL Wageningen, The Netherlands; \\ e-mail: Jan.Wieringa@wur.nl
}

\begin{abstract}
SUMMARY
As so far nobody considered the name Mussaenda schimperi Hochst. to be validly published, combinations of the superfluous name Vignaldia schimperiana A.Rich. became in use. The correct combination for this species in Pentas and that for one subspecies is presented here.
\end{abstract}

Key words: Rubiaceae, Pentas, Schimper, Africa, Ethiopia, nomenclature.

\section{INTRODUCTION}

In 1840 the 'Botanische Reiseverein Esslingen' distributed the first set of herbarium specimens collected by G.H.W. Schimper in Ethiopia. These specimens were accompanied by printed labels that bear the abbreviation U.i. for Unio itineraria, being Latin for Reiseverein, followed by the year they were distributed (Sayre 1969, Baur 1970). Following the standard set by Flora of Ethiopia and Eritrea, the first, second and third section of Plants from Abyssinia are cited using a roman number prefix for the series. The label of G.H.W. Schimper I: 38 names this plant Mussaenda schimperi Hochst. The label includes a short description of the plant: 'Frutex 1 - 3 pedalis', and hence the label itself constitutes the protologue and place of valid description of this taxon, and Schimper I: 38 automatically becomes the type. Richard (1848: 358-359) described the same species as Vignaldia schimperiana. He cited not only Schimper I: 38, but also II: 838 and II: 916 and mentioned that also Quartin Dillon collected the plant. Since Richard cited the type of Mussaenda schimperi, his name is superfluous and hence illegitimate, and following art. 7.5 of the International Code of Botanical Nomenclature its type is also Schimper I: 38 (automatic typification).

Vatke (1876) created the combination Pentas schimperiana, but by citing Richard he indirectly included the type of Mussaenda schimperi, and hence this name is illegitimate as well. Engler (1895: 92) used the combination Pentas schimperi in a list of plants of the Nglewenu Mountains in Tanzania, but since he stated neither an author nor a basionym this is not a valid recombination of Hochstetter's name.

Also Verdcourt (1953) recognised P. schimperiana and created two subspecies by combining Vignaldia occidentalis Hook.f. (Hooker 1864) as P. schimperiana subsp. occidentalis. Verdcourt stated that he selected Quartin Dillon 126 (P) as the lectotype of Vignaldia schimperiana, which is incorrect because it is against the automatic typification according to art. 7.5 of the code. 
As no valid combination of Hochstetter's name in Pentas exists, it is created here. Since in this case it was clear that all material of the species was still undistributed when the plant was described, we may assume the material as a whole was used for the description. This leads to the situation that it is unclear which sheet should be considered the holotype of the type collection, hence a lectotype is chosen.

Pentas schimperi (Hochst.) Wieringa, comb. nov.

Mussaenda schimperi Hochst., in Schimperi iter Abyssinicum Sectio prima: Plantae Adoënses. 38.

U. i. [= Unio itineraria] 1840. - Type: Schimper I: 38 (lecto WAG!, designated here; iso BR,

$\mathrm{K}, \mathrm{L}, \mathrm{MO}, \mathrm{P}, \mathrm{W})$.

= Vignaldia schimperiana A.Rich. (1848) 358-359, superfluous name.

= Pentas schimperiana (A.Rich.) Vatke (1876) 192, superfluous name.

Verdcourt (1953) considered this species to fall into two entities, a subspecies from Eastern Africa with relatively short corolla tubes and one from Central Africa with longer tubes. A comparison of his two descriptions seems to reveal some more differences, such as longer petioles, wider inflorescences, narrower corolla lobes and longer stigmas in the western subspecies, but according to Verdcourt most characters vary a lot. Examination of material at WAG reveals that some of these characters, e.g. wider inflorescences and narrower corolla lobes, are useless, while there is indeed a tendency for the western subspecies to have longer petioles and longer stigmas, although the difference is not as sharp as could be interpreted from Verdcourt's measurements. In Verdcourt's key the subspecies are keyed out using the relative length of the calyx lobes compared to the corolla, but I find it more useful to use the absolute corolla length, with in addition the stigma and petiole length. Verdcourt cited one specimen (Humbert 8857, BR) from eastern Congo (Kinshasa) as belonging to the western subspecies. Indeed, especially some of the material from eastern Congo (Kinshasa) and Rwanda shows one or more characters that better fit subsp. occidentalis, but the material I have seen is not definitely this subspecies, since other characters point to subsp. schimperi. Since such records fall within the distribution area of subsp. schimperi I prefer to assign them to that subspecies. Both subspecies seem to be restricted to volcanic soils, resulting in a major $(2200 \mathrm{~km})$ disjunction in the distribution between Cameroon and eastern Congo (Kinshasa) (reflected by the subspecific division) and smaller disjunctions within subsp. schimperi that could be as large as $700 \mathrm{~km}$. This species might be a suitable candidate for a more detailed phylobiogeographic study to reveal dispersal pathways between such ecological islands of volcanism.

Although I am a bit hesitant whether the difference between these two taxa should not be recognised at the species level instead of subspecific level, I follow Verdcourt in keeping them at subspecific level as long as no further data are available. The presented distribution data are based on Verdcourt (1953), with in addition collections present in WAG. The correct names for the subspecies are:

\section{Pentas schimperi (Hochst.) Wieringa subsp. schimperi}

Distribution - Ethiopia, Kenya, Uganda, Rwanda, Burundi, Tanzania, Malawi, Zambia, Congo (Kinshasa). 
Pentas schimperi (Hochst.) Wieringa subsp. occidentalis (Hook.f.) Wieringa, comb. nov.

Vignaldia occidentalis Hook.f. (1864) 197. - Type: Mann s.n. (lecto K, designated by Verdcourt 1953)

= Pentas schimperiana (A.Rich.) Vatke subsp. occidentalis (Hook.f.) Verdc. (1953) 266-268.

Distribution - Cameroon, Equatorial Guinea (Bioko), Sao Tomé (and Congo (Kinshasa) ?, see above).

\section{REFERENCES}

Baur, K. 1970. Der botanische Reiseverein Esslingen. Jahrb. Gesch. Oberdeut. Reichsst. 16: $228-266$.

Engler, H.G.A. 1895. Die Pflanzenwelt Ost-Afrikas und der Nachbargebiete. Theil A: Grundzüge der Pflanzenverbreitung in Deutsch-Ost-Afrika und den Nachbargebieten. Reimer, Berlin.

Hooker, J.D. 1864. On the plants of the temperate regions of the Cameroon Mountains and Islands in the Bight of Benin; collected by Mr. Gustav Mann, Government Botanist. J. Proc. Linn. Soc., Bot. 7: 171-240.

Richard, A. 1847-1848. Tentamen Florae Abyssinicae I: 472. Bertrand, Paris (p. 305-472 published in Febr. 1848).

Sayre, G. 1969. Cryptogamae Exsiccatae. An annotated bibliography of published Exsiccatae of Algae, Lichenes, Hepaticae, and Musci. Mem. New York Bot. Gard. 19: 1-174.

Vatke, G.C.W. 1876. Plantae abyssinicae collectionis nuperrimae schimperianae enumeratae auctore eodem. Linnaea 40: 183-224.

Verdcourt, B. 1953. A revision of certain African genera of herbaceous Rubiaceae. V. A revision of the genus Pentas Bentham together with a key to related genera. Bull. Rijkspl. Brussel 23: $237-371$. 